\title{
Interaction of human fibronectin with Candida glabrata epithelial adhesin 6 (Epa6)*
}

\author{
Dorota Zajac', Justyna Karkowska-Kuleta², Oliwia Bochenska1', Maria Rapala-Kozik² and \\ Andrzej Kozik ${ }^{\circledR}$
}

1Department of Analytical Biochemistry, Faculty of Biochemistry, Biophysics and Biotechnology, Jagiellonian University in Krakow, Kraków, Poland; '2Department of Comparative Biochemistry and Bioanalytics, Faculty of Biochemistry, Biophysics and Biotechnology, Jagiellonian University in Krakow, Kraków, Poland

\begin{abstract}
Adherence of pathogens to extracellular matrix proteins and host cells is one of the essential steps in the microbial colonization of the human organism. The adhesion of $C$. glabrata, i.e. the second major causative agent of human disseminated candidiases after C. albicans, to the host epithelium mainly engages specific fungal cell wall proteins - epithelial adhesins (Epa) - in particular, Epa1, Epa6 and Epa7. The aim of the present study was to identify the major Epa protein involved in the interactions with the human extracellular matrix protein - fibronectin - and to present the kinetic and thermodynamic characteristics of these interactions. A relatively novel gel-free approach, i.e. the "cell surface shaving" that consists in short treatment of fungal cells with trypsin was employed to identify the C. glabrata surfaceome. Epa6 was purified, and the isolated protein was characterized in terms of its affinity to human fibronectin using a microplate ligand-binding assay and surface plasmon resonance measurements. The dissociation constants for the binding of Epa6 to fibronectin were determined to range between $9.03 \times 10^{-9} \mathrm{M}$ and $7.22 \times 10^{-8} \mathrm{M}$, depending on the method used (surface plasmon resonance measurements versus the microplate ligand-binding assay, respectively). The identified fungal pathogen-human host protein-protein interactions might become a potential target for novel anticandidal therapeutic approaches.
\end{abstract}

Key words: Candida glabrata, epithelial adhesins, fibronectin, surface plasmon resonance

Received: 21 March, 2016; revised: 13 May, 2016; accepted: 25 May, 2016; available on-line: 30 July, 2016

\section{INTRODUCTION}

In clinical practice, a continuously increasing incidence of severe fungal diseases has been recorded over the last few decades, which has now become a serious medical problem. Candida albicans is still diagnosed as one of the major fungal pathogens of humans; however, the frequency of severe candidiases caused by other Candida species has alarmingly increased (Tadec et al., 2016). Currently, C. glabrata is considered to be the second major causative agent of fungal diseases after $C$. albicans, responsible for almost $22 \%$ of superficial and systemic candidal infections in North America and for $10 \%$ of candidiases in Europe (Perlroth et al., 2007; Bassetti et al., 2015; Gupta et al., 2015). Interestingly, C. glabrata is more closely related to baker's yeast Saccharomyces cerevisiae than to other Candida species (Dujon et al., 2004). In contrast to $C$. albicans, $C$. glabrata is strictly haploid and normally grows only in the yeast-like form (Kaur et al., 2005), although it still possesses mechanisms appropriate both for a commensal lifestyle within the human organism and for the host infection.

One of the critical steps in the infectious process, essential both for the initial stages of host colonization and for further development of disease, is the adherence of the pathogen to the host epithelial cells. Thus, many bacterial species possess complex systems, mainly localized on the cell surface, involved in detection of host ligands for further induction of the expression of specific bacterial adhesins, which allow the pathogen to attach firmly to host tissues (Kline et al., 2009). As in bacteria, the cell surface of Candida spp. is involved in adhesion of these fungi to host cells and proteins during infection. Among all cell wall components, proteins exposed on the cell surface are considered to play a key role in candidal pathogenicity (Chaffin et al., 2008; Heilmann et al., 2012). Accordingly, the interactions between proteins exposed at $C$. glabrata cell surface and human epithelial cells were characterized and shown mainly to engage Epa1, Epa6 and Epa7 (Castano et al., 2005), i.e. proteins belonging to the epithelial adhesin (Epa) family (Kaur et al., 2005; Roetzer et al., 2011). Moreover, Epa6 and Epa7 were found to contribute to strong hydrophobic interactions with various abiotic surfaces and to participate in biofilm formation on the surface of medical devices such as vascular and urinary catheters, artificial joints, stents, or implants (El-Kirat-Chatel et al., 2015; d'Enfert \& Janbon, 2016). Epa1 and Epa7 were shown to be involved in interactions with endothelial cells (Zupancic et al., 2008), whereas Epa1 could also mediate adherence to macrophages and mononuclear cells from peripheral blood (Kuhn \& Vyas, 2012).

One of the most important proteinaceous components of the extracellular matrix (ECM) is fibronectin $(\mathrm{FN})$, which is a multifunctional protein involved in

e-mail: andrzej.kozik@uj.edu.pl

${ }^{*}$ A preliminary report on the same subject was presented at 43rd Winter School of the Faculty of Biochemistry, Biophysics and Biotechnology, 16-20 February 2016, Zakopane, Poland.

Abbreviations: BSA, bovine serum albumin; CGD, Candida Genome Database; DTT, dithiothreitol; ECM, extracellular matrix; Epa, epithelial adhesin; ESI, electrospray ionization; FN, fibronectin; GPI, glycosylphosphatidylinositol; LC, liquid chromatography; LC-MS/ MS, liquid chromatography-coupled tandem mass spectrometry; MS/MS, tandem mass spectrometry; NHS, N-hydroxysuccinimide; PBS, phosphate buffered saline; SA-HRP, streptavidin-conjugated horseradish peroxidase; SDS-PAGE, sodium dodecyl sulphate polyacrylamide gel electrophoresis; SPR, surface plasmon resonance 
clotting, wound repair, and host cell adhesion and migration (Tate et al., 2002; Ghost et al., 2006). Binding of this high-molecular-mass glycoprotein on the fungal cell surface can greatly enhance the virulence of Candida species, because adsorption thereof provides a bridge to deeper tissues, thereby facilitating colonization and dissemination of pathogens within the human organism (Sturtevand \& Calderone, 1997; Nett et al., 2016). Certain proteins exposed on the surface of $C$. albicans cells, such as a typical adhesin Als1 (agglutinin-like sequence), are known to interact with FN (Donohue et al., 2011; Jordan et al., 2014). Moreover, some of the cell wallassociated proteins of non-albicans Candida species, such as C. tropicalis and C. parapsilosis, play an important role in adherence to ECM proteins (Kozik et al., 2015). For C. glabrata, the binding of N-terminal part of Epa1 to FN was only demonstrated after overexpression of this fragmental fungal protein in Escherichia coli and its purification (Ielais et al., 2014).

Since the phenomenon of fungal adhesion is based on interactions of candidal surface-exposed proteins with cells and soluble proteins of the host, in order to effectively prevent such infections, it is necessary to recognize in details the structure of the pathogen's cell wall and to understand the mechanisms of adhesion (Brunke \& Hube, 2013). In the present study, we analyzed the C. glabrata surfaceome and identified Epa6 as one of the major factors capable of binding to human FN. Furthermore, the interaction of $\mathrm{FN}$ with isolated and purified Epa6 was characterized in terms of kinetic and thermodynamic parameters.

\section{MATERIALS AND METHODS}

Yeast strain and culturing conditions. C. glabrata strain CBS138 (ATCC ${ }^{\circledR} 2001^{\mathrm{TM}}$ ) was purchased from the American Type Culture Collection (Manassas, VA, USA). Yeast cells were grown in YPD medium, pH $6.0(1 \%$ yeast extract, $2 \%$ soybean peptone and $2 \%$ glucose) (Sigma, St. Louis, MO, USA) at $37^{\circ} \mathrm{C}$ for $17 \mathrm{~h}$. To induce Epa6 surface exposition, the cells were cultured in the defined medium RPMI 1640, pH 7.4 (PAA Laboratories $\mathrm{GmbH}$, Pasching, Austria) at $37^{\circ} \mathrm{C}$ for $72 \mathrm{~h}$. In this particular case, human FN (R\&D Systems, Minneapolis, MN, USA) was added to the YPD medium to a final concentration of $0.2 \mathrm{mg} / \mathrm{ml}$.

Experimental strategy. We used four sets of experiments aimed to identify major FN-binding proteins of C. glabrata cell wall that finally allowed to assign this activity to Epa6 protein:

(i) the extraction of cell wall-associated proteins with $\beta-1,6$-glucanase from $C$. glabrata cells cultured in YPD and RPMI media and the analysis of these extracts for FN binding;

(ii) Epa6 purification, using a protocol including: ion exchange chromatography, selection of fractions with FN-binding activity, gel filtration;

(iii) kinetic and thermodynamic characterization of the interactions between purified Epa6 and FN, using a microplate ligand-binding assay and SPR measurements;

(iv) tryptic "shaving" of C. glabrata cells cultured in the presence of $\mathrm{FN}$, followed by the identification of cell surface-exposed proteins.

Extraction of cell wall-associated proteins. The cell wall-associated proteins were extracted from both biotinylated and non-biotinylated cells, using the previously published protocols (Kozik et al., 2015). Briefly, to biotinylate the proteins associated with the fungal cell wall,
$1 \mathrm{~g}$ (wet weight) of the C. glabrata cells (YPD-cultured at $37^{\circ} \mathrm{C}$ for $17 \mathrm{~h}$ or RPMI 1640 -cultured at $37^{\circ} \mathrm{C}$ for $72 \mathrm{~h}$ ) was suspended in $0.1 \mathrm{M}$ bicarbonate buffer, $\mathrm{pH} 8.3$ and a solution of N-hydroxysuccinimide-biotin (NHS-biotin, Sigma) in dimethylformamide $(1 \mathrm{mg} / 50 \mu \mathrm{l})$ was added, followed by sample incubation for $1 \mathrm{~h}$ at room temperature in the dark. After incubation, the cells were extensively washed with $50 \mathrm{mM}$ phosphate buffer ( $\mathrm{pH}$ 6.0) in order to remove the excess reagent. Next, the fungal cells were placed in $1 \mathrm{ml}$ of McIlvaine buffer (a mixture of $0.1 \mathrm{M}$ citric acid and $0.2 \mathrm{M}$ disodium phosphate, $\mathrm{pH}$ 6.0, with $0.5 \mathrm{M}$ sodium tartrate as an osmotic stabilizer) and treated with $2 \mathrm{U}$ of $\beta-1,6$-glucanase for $24 \mathrm{~h}$ at $37^{\circ} \mathrm{C}$. After extraction, the supernatants were collected and dialyzed against phosphate buffered saline (PBS), $\mathrm{pH} 7.4$, at $4^{\circ} \mathrm{C}$ for $48 \mathrm{~h}$. Cell membrane integrity was tested by staining with Trypan Blue (Sigma). The protein mixtures obtained were characterized by sodium dodecyl sulfate polyacrylamide gel electrophoresis (SDS-PAGE) in the Laemmli system (Laemmli, 1970).

Analysis of binding of biotinylated cell wall-associated proteins to microplate-immobilized FN. FN was immobilized in the wells of the MaxiSorp 96-well microplate (Sarstedt, Nümbrecht, Germany) by overnight incubation at $4^{\circ} \mathrm{C}$ ( $5 \mathrm{pmol}$ of protein per well). The unoccupied surface in each well was blocked with 3\% BSA in PBS at $4^{\circ} \mathrm{C}$ overnight. Solutions of biotinylated fungal protein in PBS with $10 \mathrm{mM}$ calcium chloride $(50 \mu \mathrm{l})$ were added to the wells and then the microplate was incubated at $37^{\circ} \mathrm{C}$ for $1.5 \mathrm{~h}$. The amounts of bound biotinylated proteins were determined with the use of a SAHRP/TMB detection system (Rapala-Kozik et al., 2008).

Purification of Epa6. Ion-exchange chromatography. The mixture of the extracted cell wall-associated proteins was dialyzed against $20 \mathrm{mM}$ Tris- $\mathrm{HCl}$ buffer for $48 \mathrm{~h}$ and then applied to a Resource Q column (6.4 mm $\times 30$ $\mathrm{mm}$, particle size $15 \mu \mathrm{m}$ ) (Pharmacia Biotech, Uppsala, Sweden). The proteins were eluted using a $20 \mathrm{ml}$ linear gradient of $0-0.5 \mathrm{M} \mathrm{NaCl}$ at a flow rate of $1 \mathrm{ml} /$ min. Fractions (1 min) were collected and analyzed for: (i) SDS-PAGE characteristics; (ii) FN-binding activity, and (iii) the presence of Epa proteins (identified by mass spectrometry).

Competitive FN-binding assay of fractions obtained from ion-exchange chromatography. Fractions eluted from the Resource Q column were analyzed for a competition with biotinylated cell wall proteins for binding to the microplate-adsorbed FN. For this assay, FN was immobilized in the wells of the MaxiSorp 96-well microplate (Sarsted) by overnight incubation at $4^{\circ} \mathrm{C}(5 \mathrm{pmol}$ protein per well). After this and all following steps, the wells were washed three times with $1 \%$ BSA in PBS buffer. The unoccupied surface in each well was blocked with $3 \%$ BSA in PBS at $4^{\circ} \mathrm{C}$ by overnight incubation. The mixture of biotinylated cell wall-extracted proteins at a concentration of $20 \mu \mathrm{g} / \mathrm{ml}(25 \mu \mathrm{l})$ with a given fraction from Resource Q chromatography $(25 \mu \mathrm{l})$ was added to the wells and the plate was incubated at $37^{\circ} \mathrm{C}$ for $1.5 \mathrm{~h}$. The wells with biotinylated cell wall-extracted proteins, diluted two-fold with PBS $(50 \mu \mathrm{l})$, represented the maximal binding (taken as $100 \%$ ). The amounts of bound proteins were determined with the use of the SA-HRP/TMB detection system. The wells without FN, which were surface-blocked with $3 \%$ BSA, served as a control. The values obtained for the control samples were subtracted from the total binding.

Selection of Epa6-containing fractions. To identify the content of protein bands on SDS-PAGE gels, the bands were manually excised and destained in $25 \%$ acetonitrile 
(ACN) and then in 50\% ACN in $25 \mathrm{mM} \mathrm{NH} \mathrm{HCO}_{3}$. The next step was reduction with $50 \mathrm{mM}$ DT'T in 25 $\mathrm{mM} \mathrm{NH} \mathrm{HCO}_{3}$ at $37^{\circ} \mathrm{C}$ for $45 \mathrm{~min}$, followed by alkylation with $55 \mathrm{mM}$ iodoacetamide in $25 \mathrm{mM} \mathrm{NH}_{4} \mathrm{HCO}_{3}$ for $90 \mathrm{~min}$ at room temperature in the dark. The excess reagents were washed out with 50\% ACN. The gel pieces were then dehydrated in $100 \% \mathrm{ACN}$ and dissolved in $13 \mu \mathrm{l}$ of a trypsin (Promega, Madison, WI, USA) solution $\left(0.2 \mu \mathrm{g} / \mu \mathrm{l}\right.$ in $\left.25 \mathrm{mM} \mathrm{NH} \mathrm{HCO}_{3}\right)$, followed by the incubation of the sample for $15 \mathrm{~min}$ at room temperature. After addition of $20 \mu \mathrm{l}$ of $25 \mathrm{mM} \mathrm{NH} \mathrm{HCO}_{3}$, the digestion was continued at $37^{\circ} \mathrm{C}$ overnight. Peptides were extracted by sonication in $50 \% \mathrm{ACN}$ and $0.5 \%$ formic acid at $37^{\circ} \mathrm{C}$. The peptides obtained were separated and analyzed by liquid chromatography-coupled tandem mass spectrometry (LC-MS/MS), following protocols described previously (Karkowska-Kuleta et al., 2015).

Gel filtration. After separation on the Resource Q column, Epa6-containing fractions were injected onto a TSK G $3000 \mathrm{SW}$ column $(21.5 \mathrm{~mm} \times 30 \mathrm{~cm}$, particle size $13 \mu \mathrm{m}$ ) (Tosoh Bioscience, USA). The column was eluted with $0.1 \mathrm{M}$ sodium sulfate and $0.1 \mathrm{M}$ sodium dihydrogen phosphate, $\mathrm{pH}$ 6.7. Proteins were separated at a flow rate of $2 \mathrm{ml} / \mathrm{min}$. Fractions were collected, characterized by SDS-PAGE and analyzed by LC-MS/MS.

Labeling of Epa6 with fluorescein. A solution (1 $\mathrm{mg} / 100 \mu \mathrm{l}$ ) of NHS-fluorescein (Thermo Fisher Scientific, Waltham, MA, USA) in dimethyl sulfoxide was added to purified Epa6 $(100 \mu \mathrm{g})$ in $200 \mu \mathrm{l}$ of $0.1 \mathrm{M}$ bicarbonate buffer, $\mathrm{pH} 8.3$, and the mixture was incubated at $4^{\circ} \mathrm{C}$ for $4 \mathrm{~h}$, followed by dialysis against PBS at $4^{\circ} \mathrm{C}$ for $48 \mathrm{~h}$.

Binding of fluorescein-labeled Epa6 to microplate-immobilized FN. For this version of the FNbinding test, FN was immobilized in the wells of the MaxiSorp 96-well microplate (Sarsted) by overnight incubation at $4^{\circ} \mathrm{C}(3 \mathrm{pmol}$ protein per well). The unoccupied surface in each well was blocked with $0.5 \%$ BSA in PBS at $37^{\circ} \mathrm{C}$ for $3 \mathrm{~h}$. Solutions $(50 \mu \mathrm{l})$ of fluorescein-labeled proteins at increasing concentrations in PBS with $10 \mathrm{mM}$ calcium chloride were added to the wells and the plate was incubated at $37^{\circ} \mathrm{C}$ for $1.5 \mathrm{~h}$. The amounts of bound proteins were determined with the use of a fluorometric microplate reader model Synergy H1 (BioTek, Winooski, VT, USA). The wells with immobilized FN and filled with solutions containing fluorescein-labeled Epa6 (at the given concentration) and ten-fold molar excess of unlabeled Epa6 served as controls for " non-specific" binding. The signals for non-specific binding were subtracted from the total binding signals. A one-site binding model was fitted to the experimental data with the use of GraphPad Prism software.

Quantitative surface plasmon resonance (SPR) analysis of Epa6 binding to FN. FN was immobilized on CM5 chips of the BIACORE 3000 system (GE Healthcare, Uppsala, Sweden) in $10 \mathrm{mM}$ sodium acetate buffer, $\mathrm{pH}$ 4.5. The immobilization was performed at $25^{\circ} \mathrm{C}$ with a flow rate of $10 \mu \mathrm{l} / \mathrm{min}$ for $7 \mathrm{~min}$ using an Amine Coupling Kit (GE Healthcare), i.e. the mixture of $50 \mathrm{mM}$ 1-ethyl-3-(3-dimethylaminopropyl)carbodiimide (EDC) and $200 \mathrm{mM} \mathrm{N}$-hydroxysuccinimide (NHS). The remaining activated ester groups were blocked with ethanolamine. The immobilization level reached ca. 280 resonance units (RU). The Epa6 solution was pre-dialyzed against a running buffer $(10 \mathrm{mM}$ HEPES, 150 $\mathrm{mM}$ sodium chloride, $10 \mathrm{mM}$ calcium chloride, $0.005 \%$, $\mathrm{w} / \mathrm{v}$, surfactant P20, $\mathrm{pH}$ 7.4) and then injected (a concentration range of $5-125 \mathrm{nM}$ ) through the chip flow cells with immobilized FN (and a control cell without $\mathrm{FN}$ ) at a flow rate of $30 \mu \mathrm{l} / \mathrm{min}$. The association and dissociation time was $120 \mathrm{~s}$. The chip surface was regenerated between binding cycles by injection of $1 \mathrm{M} \mathrm{NaCl}$ for 30 seconds. The binding parameters were obtained by the analysis of sensograms using BIAevaluation 4.1 software (GE Healthcare). The dissociation and association rate constants $\left(k_{\mathrm{d}}\right.$ and $\left.k_{\mathrm{s}}\right)$ were obtained on the basis of a global fit with a simple Langmuir model (1:1) with a drifting baseline, and the $K_{\mathrm{D}}$ values were calculated as the ratios of the rate constants.

Cell surface shaving with trypsin. Protocols described previously (Karkowska-Kuleta et al., 2015) were used in the analysis. Briefly, after culturing C. glabrata yeast in YPD medium, $2 \times 10^{7}$ cells were washed with $25 \mathrm{mM}$ ammonium bicarbonate buffer $\left(\mathrm{NH}_{4} \mathrm{HCO}_{3}\right)$, suspended in $100 \mu \mathrm{l}$ of the same buffer with $5 \mathrm{mM}$ dithiothreitol (DTT), and treated with sequencing-grade trypsin $(10 \mu \mathrm{g})$ (Promega, Madison, WI, USA) at $37^{\circ} \mathrm{C}$ for $5 \mathrm{~min}$. After centrifugation (5 minutes, $6000 \mathrm{rpm}$ ) and filtration through a filter with $0.22 \mu \mathrm{m}$-diameter pores, the supernatant was subjected to further incubation with trypsin for $5 \mathrm{~h}$ at the same temperature. To stop the enzymatic reaction, trifluoroacetic acid (TFA) (Sigma) was added to the supernatant (final concentration of $0.1 \%$ ). After incubation on ice for $15 \mathrm{~min}$, the sample was centrifuged (15 min, $12000 \mathrm{rpm})$, dried in a Speed-Vac (Martin Christ, Osterode am Harz, Germany) and frozen until further use. The cells that remained in the pellet were tested for cell membrane integrity by Trypan Blue (Sigma) staining.

Protein identification with LC-MS/MS. The peptides were analyzed with a HCTUltra ETDII ion-trap mass spectrometer equipped with an electrospray ionization ion source (Bruker, Bremen, Germany) and coupled to an ultra-high-performance liquid chromatograph Dionex Ultimate 3000 system (Thermo Scientific, Waltham, MA, USA). Protocols described previously (KarkowskaKuleta et al., 2015) were used in the analysis. Briefly, after dissolution in $100 \mu \mathrm{l}$ loading buffer $(10 \% \mathrm{ACN}$ with $0.1 \%$ formic acid), all peptide samples were separated on an Accucore C18 column $(100 \mathrm{~mm} \times 2.1 \mathrm{~mm}$, particle size $2.6 \mu \mathrm{m}$ ) (Thermo Fisher Scientific) with a 60 min gradient (from 10 to $60 \%$ of phase B) at a flowrate of $0.2 \mu \mathrm{l} / \mathrm{min}$. Mascot Generic format (.mgf) files were generated by Data Analysis 4.0 software (Bruker). The lists of the peaks obtained were searched against the NCBI protein database with taxonomy restriction to the Fungi or Swiss Prot protein database with taxonomy restriction to Homo sapiens, using an in-house Mascot server (v.2.3.0; Matrix Science, London, UK). The following search parameters were applied: enzyme specificity trypsin; permitted number of missed cleavages - 2; fixed modification - carbamidomethylation (C); variable modifications - oxidation ( $\mathrm{M})$; protein mass - unrestricted; peptide mass tolerance of $\pm 0.3 \mathrm{Da}$ and fragment mass tolerance of $\pm 0.5 \mathrm{Da}$.

\section{RESULTS}

\section{Binding of immobilized FN by C. glabrata cell wall- extracted proteins}

After culturing the yeast cells in the YPD or RPMI 1640 media, C. glabrata cell wall proteome was revealed and found to differ to some extent depending on growth conditions. For instance, after "cell surface shaving", the typical adhesin Epa6 was found only on the cell surface after growth in the RPMI 1640 medium (data not shown). A mixture of cell wall-associated proteins, used in further studies was obtained after releasing proteins 


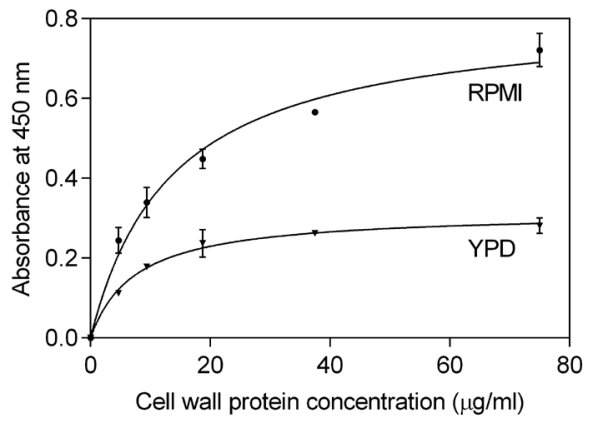

Figure 1. Binding of biotinylated C. glabrata cell wall proteins to microplate-immobilized FN.

Before extraction with $\beta-1,6-$ glucanase, the cells were cultured at different conditions $\left(17 \mathrm{~h}\right.$ at $30^{\circ} \mathrm{C}$ in the YPD medium or $72 \mathrm{~h}$ at $37^{\circ} \mathrm{C}$ in the RPMI medium). Cell wall-extracted proteins at a concentration in the range of $1.5-75 \mu \mathrm{g} / \mathrm{ml}$ were added to immobilized FN. The wells without FN, which were surface-blocked with $3 \%$ BSA, served as a control. The non-specific binding level was estimated from the readings of wells without immobilized FN and this value was subtracted from the total binding. Data points represent mean values from three determinations (three wells) \pm standard deviation.

from the cell wall with $\beta-1,6$-glucanase. After this treatment, more than $95 \%$ of yeast cells remained viable. Plots for saturable binding of biotin-labelled cell wallextracted proteins to microplate-immobilized $\mathrm{FN}$ are shown in Fig. 1. The FN-binding capacity of the proteins isolated from yeasts grown in the RPMI 1640 medium was three-fold higher than that of proteins from YPD-cultured yeasts.

\section{Purification of Epa6 as a major FN-binding protein of the C. glabrata cell wall}

The whole mixture of proteins obtained by $\beta-1,6-$ glucanase treatment of $C$. glabrata cells cultured in the RPMI 1640 medium were subjected to ion-exchange chromatography on Resource Q column (Fig. 2). A competitive ligand-binding assay was applied in order to identify FN-binding proteins in fractions obtained during

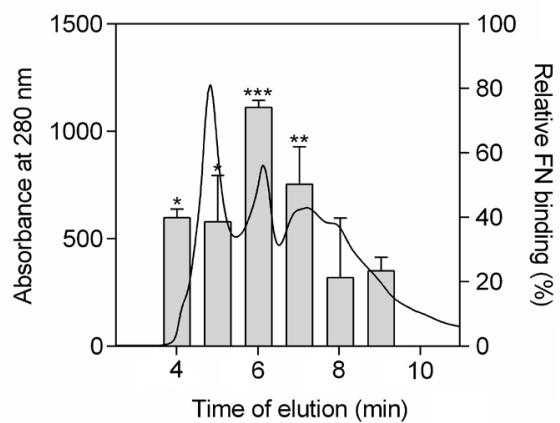

Figure 2. Separation of C. glabrata cell wall proteins by ion-exchange chromatography on the Resource $\mathrm{Q}$ column, with monitoring FN-binding activity.

The mixture of extracted cell wall proteins were separated as described in the text. A representative chromatogram is presented as a solid line. Fractions (1 $\mathrm{min}$ ) were collected and analyzed for FN-binding activity (bars) using a competitive assay. To this end, biotinylated cell wall proteins (final concentration of $20 \mu \mathrm{g} / \mathrm{ml}$ ), mixed with chromatographic fractions (in the figure marked with the corresponding elution time) were added to immobilized FN. The statistical significance of the signals obtained against the signal from the control sample containing the biotinylated proteins without any competitor is indicated by asterisks: ${ }^{*} p<0.05$, ${ }^{* *} p<0.005,{ }^{* * *} p<0.001$.

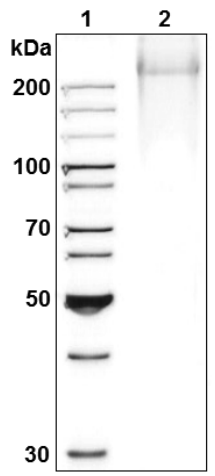

Figure 3. SDS-PAGE analysis of purified C. glabrata epithelial adhesin 6.

A sample of purified Epa6 ( $3 \mu \mathrm{g}$ ) was analyzed on $10 \%$ gel in the Laemmli system under reducing conditions. After SDS-PAGE the protein bands were visualized by silver staining. Lane 1: molecular mass standard; lane 2: purified Epa6.

the protein separation procedure. The assay was based on the use of microplate-immobilized FN and the analysis of the competition between the proteins contained in the collected fractions and the whole mixture of biotinylated fungal cell wall-associated proteins isolated with $\beta-1,6$-glucanase. Several fractions were found to exhibit a detectable FN-binding ability (up to $70 \%$ displacement in the competitive assay). These fractions were analyzed by SDS-PAGE, and the proteins, contained in the individual bands visualized on the gel were identified by LC-MS/MS (Table 1). Three fractions (elution times of 5-7 min), representing the maximal FN-binding ability in the competitive assay, were found to contain epithelial adhesins, Epa3 and Epa6. The Epa6-containing fraction (eluted at $7 \mathrm{~min}$ ) was subjected to high-performance gel filtration on a TSK 3000 G SW column, yielding a reasonably pure protein, represented by a single although slightly diffused band in SDS-PAGE (Fig. 3). It was unequivocally confirmed by LC-MS/MS to contain Epa6 as the only detectable component (in-gel digestion with trypsin, Mascot score of $312,34 \%$ sequence coverage). However, the molecular mass of this protein was much higher than that calculated from Epa6 amino acid sequence $(78 \mathrm{kDa})$, reflecting the heavily mannosylated status of Epa molecules. A slight heterogeneity of the

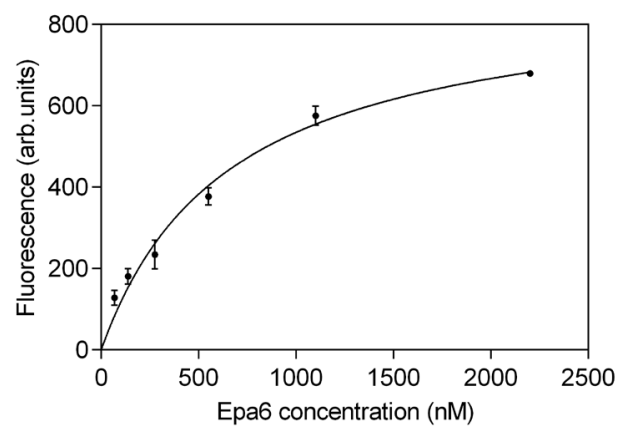

Figure 4. A microplate assay for testing the interactions of purified Epa6 with fibronectin.

The binding plot was obtained after incubation of the fluorescein-labeled Epa6 (concentration range of 6-220 nM) with immobilized FN. The applied experimental protocol is described under Methods section. The values obtained for control samples (the mixtures of fluorescein-labeled Epa6 with 10-fold molar excess of unlabeled Epa6) were subtracted from the total binding. Data points represent mean values from three determinations (three wells) \pm standard deviation. 
Table 1. Mass spectrometry identification of proteins present in fractions obtained during the separation of $C$. glabrata cell wall proteins on Resource $Q$ column.

After SDS-PAGE analysis, major protein bands were excised from the gel and subjected to digestion with trypsin. The peptides obtained were analyzed by LC-MS/MS.

\begin{tabular}{|c|c|c|}
\hline Fraction $(\min )^{*}$ & Major proteins identified & $\begin{array}{l}\text { Protein concentration } \\
(\mathrm{mg} / \mathrm{ml})\end{array}$ \\
\hline 4 & $\begin{array}{l}\text { hypothetical protein [Candida glabrata CBS 138] similar to Saccharomyces cerevisiae putative } \\
\text { GPI-linked cell wall mannoprotein of the Srp1p/Tip1p family }\end{array}$ & 0.11 \\
\hline 5 & $\begin{array}{l}\text { epithelial adhesin } 3 \text { [Candida glabrata CBS 138], } \\
\text { hypothetical protein [Candida glabrata CBS 138] highly similar to Saccharomyces cerevisiae } \\
\text { enolase I (Eno1), } \\
\text { hypothetical protein [Candida glabrata CBS 138] highly similar to Saccharomyces cerevisiae } \\
\text { transaldolase (Tal1), } \\
\text { hypothetical protein [Candida glabrata CBS 138] highly similar to Saccharomyces cerevisiae } \\
\text { cobalamin-independent methionine synthase (Met6) }\end{array}$ & 0.18 \\
\hline 6 & $\begin{array}{l}\text { epithelial adhesin } 3 \text { [Candida glabrata CBS 138], } \\
\text { epithelial adhesin } 6 \text { [Candida glabrata CBS 138], } \\
\text { hypothetical protein [Candida glabrata CBS 138] highly similar to Saccharomyces cerevisiae } \\
\text { glucose-6-phosphate isomerase (Pgi) }\end{array}$ & 0.15 \\
\hline 7 & $\begin{array}{l}\text { epithelial adhesin } 6 \text { [Candida glabrata CBS 138], } \\
\text { hypothetical protein [Candida glabrata CBS 138] highly similar to Saccharomyces cerevisiae } \\
\text { triose phosphate isomerase (Tpi), } \\
\text { hypothetical protein [Candida glabrata CBS 138] similar to Saccharomyces cerevisiae cell wall } \\
\text { mannoprotein (Cwp1), } \\
\text { hypothetical protein [Candida glabrata CBS 138] highly similar to Saccharomyces cerevisiae } \\
\text { endo-beta-1,3-glucanase (Bgl2), } \\
\text { hypothetical protein [Candida glabrata CBS 138] highly similar to Saccharomyces cerevisiae } \\
\text { glyceraldehyde-3-phosphate dehydrogenase (Tdh3) }\end{array}$ & 0.36 \\
\hline 8 & $\begin{array}{l}\text { hypothetical protein [Candida glabrata CBS 138] highly similar to Saccharomyces cerevisiae } \\
\text { extracellular mutant (Ecm4), } \\
\text { hypothetical protein [Candida glabrata CBS 138] highly similar to Saccharomyces cerevisiae } \\
\text { triose phosphate isomerase (Tpi) }\end{array}$ & 0.11 \\
\hline 9 & $\begin{array}{l}\text { hypothetical protein [Candida glabrata CBS 138] highly similar to Saccharomyces cerevisiae } \\
\text { haze protective factor (Hpf1), } \\
\text { hypothetical protein [Candida glabrata CBS 138] highly similar to Saccharomyces cerevisiae } \\
\text { member of the FLO family of cell wall flocculation proteins (Flo10) }\end{array}$ & 0.10 \\
\hline
\end{tabular}

*1-ml fraction collected at the indicated elution time

polysaccharide moiety could account for the diffused appearance of the electrophoretic band.

\section{Kinetic and thermodynamic characterization of the interaction between FN and purified C. glabrata Epa6}

First, the interaction of purified Epa6 with $\mathrm{FN}$ was directly demonstrated by the semi-quantitative microplate ligand-binding assay (Fig. 4). Through fitting a simple model, i.e. one-site binding (hyperbola), to the experimental data, the $K_{0.5}$ parameter, which is a rough approximation of the dissociation constant $\left(K_{D}\right)$ for the binding of fluorescein-labeled Epa6 to microplate-immobilized $\mathrm{FN}$, was estimated at $7.22 \times 10^{-8} \mathrm{M}$.

The quantitative SPR method was then applied to characterize the Epa6-FN interaction in terms of kinetics and thermodynamics. To this end, FN was immobilized on the CM5 chips of the BIACORE 3000 system. The sensograms obtained for binding of Epa6 to chipimmobilized FN are presented in Fig. 5. A good global fit to the sensograms was obtained with the Langmuir 1:1 binding model with a drifting baseline, resulting in the binding parameters specified in Fig. 5.

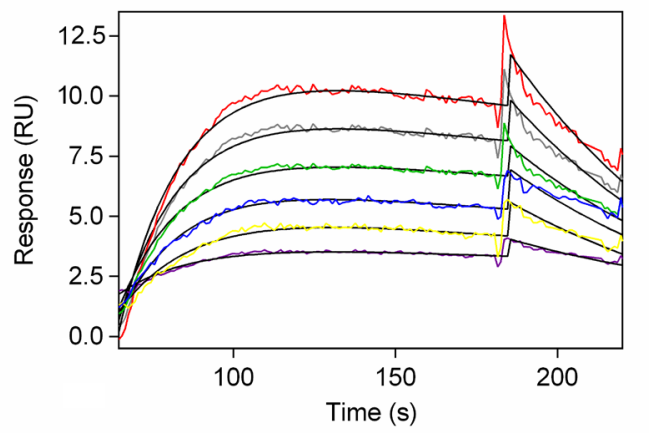

Concentration of Epa6:

$-5 \mathrm{nM}$

$25 \mathrm{nM}$

$-50 \mathrm{nM}$

- $75 \mathrm{nM}$

$100 \mathrm{nM}$

- $125 \mathrm{nM}$

$k_{a}=4.58 \times 10^{5} \pm 2.03 \times 10^{4}\left(\mathrm{M}^{-1} \mathrm{~s}^{-1}\right)$

$k_{d}=4.14 \times 10^{-3} \pm 1.63 \times 10^{-4}\left(\mathrm{~s}^{-1}\right)$

$K_{D}=9.03 \times 10^{-9} \pm 3.14 \times 10^{-11}(\mathrm{M})$

Figure 5. SPR analysis of the interaction of Epa6 with FN.

Sensograms were obtained after injection of Epa6 (concentration of the analyte within a range of 5-125 nM) over a CM5 chip containing immobilized FN (level: $280 \mathrm{RU}$ ) at a flow rate of $30 \mu \mathrm{l} / \mathrm{min}$. A Langmuir 1:1 binding model with a drifting baseline was well fitted to the sensograms, as shown by the black lines.

\section{Identification of C. glabrata cell surface-exposed proteins}

A gel-free approach, i.e. the "cell surface shaving", consisting in short treatment of fungal cells with trypsin, was used to identify proteins that were exposed on the surface of yeast cells cultured under different environmental conditions (YPD medium vs. YPD supplemented with $\mathrm{FN}$ ). A procedure that had been previously applied to analyze $C$. tropicalis and C. parapsilosis "surfaceomes" (KarkowskaKuleta et al., 2015) was used in this study. The yeast cell integrity was checked in each experiment with the use of Trypan Blue staining, because the crucial requirement for 
Table 2. Mass spectrometry analysis of proteins identified at the cell surface of $C$. glabrata.

The yeast cells were cultured at $37^{\circ} \mathrm{C}$ for $17 \mathrm{~h}$ in YPD medium or in the presence of FN in the same medium. After "cell surface shaving" with trypsin and additional digestion of obtained proteins for 5 hours, peptides were analyzed by LC-MS/MS. The obtained lists of peaks were searched against the NCBI protein database with taxonomy restriction - Fungi and SwissProt protein database with taxonomy restriction - Human, using in-house Mascot server (SC - sequence coverage).

\begin{tabular}{|c|c|c|c|c|c|c|c|c|}
\hline \multicolumn{9}{|c|}{ Surface-exposed fungal proteins } \\
\hline Accession & Protein description & $\begin{array}{l}\text { Molecular } \\
\text { mass } \\
{[\mathrm{kDa}]}\end{array}$ & pl & Score & $\begin{array}{l}\text { Number of } \\
\text { peptides }\end{array}$ & $\begin{array}{l}\mathrm{SC} \\
{[\%]}\end{array}$ & YPD & $\begin{array}{l}\text { YPD + } \\
\text { FN }\end{array}$ \\
\hline gi|50289857 & $\begin{array}{l}\text { hypothetical protein [Candida glabrata } \\
\text { CBS 138] highly similar to Saccharomyces } \\
\text { cerevisiae enolase I (Eno1) }\end{array}$ & 46.8 & 4.23 & 1052 & 19 & 50 & + & + \\
\hline gi|50288681 & $\begin{array}{l}\text { hypothetical protein [Candida glabrata } \\
\text { CBS 138] highly similar to Saccharomyces } \\
\text { cerevisiae glyceraldehyde-3-phosphate } \\
\text { dehydrogenase (Tdh3) }\end{array}$ & 36.0 & 6.19 & 727 & 17 & 59 & + & + \\
\hline gi|25992752 & $\begin{array}{l}\text { pyruvate decarboxylase (Pdc) [Candida } \\
\text { glabrata CBS 138] }\end{array}$ & 62.0 & 4.57 & 514 & 12 & 29 & + & + \\
\hline gi|50290317 & $\begin{array}{l}\text { hypothetical protein [Candida glabrata } \\
\text { CBS 138] highly similar to Saccharomyces } \\
\text { cerevisiae alcohol dehydrogenase I (Adh1) }\end{array}$ & 37.9 & 4.60 & 444 & 9 & 37 & + & + \\
\hline gi|50291073 & $\begin{array}{l}\text { hypothetical protein [Candida glabrata } \\
\text { CBS 138] highly similar to Saccharomyces } \\
\text { cerevisiae secreted glycoprotein (Ygp1) }\end{array}$ & 37.8 & 4.24 & 392 & 10 & 30 & + & + \\
\hline gi|50288201 & $\begin{array}{l}\text { hypothetical protein [Candida glabrata } \\
\text { CBS 138] highly similar to Saccharomyces } \\
\text { cerevisiae stress-seventy subfamily A } \\
\text { (Ssa2) }\end{array}$ & 69.6 & 4.33 & 388 & 10 & 27 & + & + \\
\hline gi|50292893 & $\begin{array}{l}\text { hypothetical protein [Candida glabrata } \\
\text { CBS 138] highly similar to Saccharomyces } \\
\text { cerevisiae fructose-bisphosphate aldolase } \\
\text { (Fba1) }\end{array}$ & 39.5 & 4.75 & 292 & 6 & 18 & + & + \\
\hline gi|50285959 & $\begin{array}{l}\text { hypothetical protein [Candida glabrata } \\
\text { CBS 138] highly similar to Saccharomy- } \\
\text { ces cerevisiae stress-seventy subfamily B } \\
\text { (Ssb2) }\end{array}$ & 66.5 & 5.14 & 280 & 5 & 13 & + & + \\
\hline gi|50293403 & $\begin{array}{l}\text { hypothetical protein [Candida glabrata } \\
\text { CBS 138] highly similar to Saccharomyces } \\
\text { cerevisiae phosphoglycerate kinase (Pgk1) }\end{array}$ & 44.7 & 7.80 & 209 & 6 & 18 & + & + \\
\hline gi|50292725 & $\begin{array}{l}\text { hypothetical protein [Candida glabrata } \\
\text { CBS 138] highly similar to Saccharomyces } \\
\text { cerevisiae heat shock protein (Hsc82) }\end{array}$ & 81.0 & 4.48 & 165 & 4 & 10 & + & + \\
\hline gi|50295024 & $\begin{array}{l}\text { hypothetical protein [Candida glabrata } \\
\text { CBS } 138 \text { ] highly similar to Saccharomyces } \\
\text { cerevisiae 6-phosphogluconate dehydro- } \\
\text { genase (Gnd1) }\end{array}$ & 53.9 & 6.60 & 121 & 3 & 10 & + & + \\
\hline gi|50284959 & $\begin{array}{l}\text { hypothetical protein [Candida glabrata } \\
\text { CBS 138] highly similar to Saccharomyces } \\
\text { cerevisiae elongation factor } 2 \text { (Ef2) }\end{array}$ & 93.8 & 4.72 & 113 & 4 & 8 & + & + \\
\hline gi|50286075 & $\begin{array}{l}\text { hypothetical protein [Candida glabrata } \\
\text { CBS 138] highly similar to Saccharomyces } \\
\text { cerevisiae translation elongation factor } \\
\text { (Tef1) }\end{array}$ & 50.2 & 9.58 & 155 & 4 & 14 & + & \\
\hline gi|50287821 & $\begin{array}{l}\text { hypothetical protein [Candida glabrata } \\
\text { CBS 138] highly similar to Saccharomyces } \\
\text { cerevisiae elongation factor beta (Efb1) }\end{array}$ & 23.0 & 4.05 & 152 & 3 & 32 & + & \\
\hline gi|50284963 & $\begin{array}{l}60 \text { S ribosomal protein L19 [Candida gla- } \\
\text { brata CBS 138] }\end{array}$ & 21.7 & 11.9 & 115 & 3 & 14 & + & \\
\hline gi|3786314 & $\begin{array}{l}\text { translation elongation factor3 [Candida } \\
\text { glabrata CBS 138] }\end{array}$ & 116.8 & 5.91 & 109 & 2 & 2 & + & \\
\hline gi|32563290 & $\begin{array}{l}\text { translation elongation factor 1-alpha, } \\
\text { partial (Tef1) [Candida glabrata CBS 138] }\end{array}$ & 50.2 & & 270 & 7 & 20 & & + \\
\hline gi|50293029 & $\begin{array}{l}\text { hypothetical protein [Candida glabrata } \\
\text { CBS 138] highly similar to Saccharomyces } \\
\text { cerevisiae malate synthase (Mls1) }\end{array}$ & 63.5 & 7.20 & 207 & 6 & 15 & & + \\
\hline gi|50285355 & $\begin{array}{l}\text { hypothetical protein [Candida glabrata } \\
\text { CBS 138] highly similar to Saccharomyces } \\
\text { cerevisiae transaldolase (Tal1) }\end{array}$ & 36.8 & 6.33 & 198 & 3 & 14 & & + \\
\hline
\end{tabular}




\begin{tabular}{|c|c|c|c|c|c|c|c|}
\hline gi|50285407 & $\begin{array}{l}\text { hypothetical protein [Candida glabrata } \\
\text { CBS 138] similar to Saccharomyces cerevi- } \\
\text { siae protein with similarity to a family of } \\
\text { flavodoxin-like proteins (Pst2) }\end{array}$ & 29.9 & 5.55 & 169 & 3 & 24 & + \\
\hline gi|49617210 & $\begin{array}{l}\text { epithelial adhesin } 6 \text { [Candida glabrata } \\
\text { CBS 138] }\end{array}$ & 78.6 & 5.28 & 100 & 2 & 4 & + \\
\hline \multicolumn{8}{|c|}{ Surface-bound human proteins } \\
\hline FINC_HUMAN & $\begin{array}{l}\text { fibronectin } \mathrm{OS}=\text { homo sapiens } \mathrm{GN}=\mathrm{FN} 1 \\
\mathrm{PE}=1 \mathrm{SV}=4\end{array}$ & 266 & & 249 & 14 & 12 & + \\
\hline
\end{tabular}

the whole treatment was that cell membranes remain intact, i.e., no cell lysis could occur.

This method allowed identification of 16 and 17 proteins, assigned to cells grown in the YPD medium and the YPD medium with FN, respectively. A list of the identified proteins is presented in Table 2. As shown, 12 of the identified proteins were common in yeasts cultured in either conditions, but some proteins were unique, as for example Epa6, which was found on the cell surface only if FN was added to the cultivation medium. All abbreviated names and protein descriptions included in this study were taken from the NCBI protein database and the Candida Genome Database (CGD). Because the genome sequence of $C$. glabrata is still poorly described, the identified proteins were compared and assigned to orthologous genes/proteins from baker's yeast $S$. cerevisiae.

\section{DISCUSSION}

Despite its close relatedness to the non-pathogenic yeast $S$. cerevisiae, C. glabrata has become the second fungal pathogen in the USA and the third in Europe in terms of the frequency of infections caused (Mikulska et al., 2012; Pfaller et al., 2012). Admittedly, issues concerning $C$. glabrata pathogenicity have been the subject of quite extensive studies in recent years; however, disseminated infections caused by this Candida species, partly due to the high drug resistance of this fungus, are a serious problem in the current clinical practice.

Although $C$. albicans and $C$. glabrata are considered as two Candida species that are most commonly distributed in the human population, they markedly differ in terms of their phylogenetic, genetic and phenotypic features (Polke et al., 2015). Nevertheless, the main goals during the invasion of host cells - nutrient acquisition and immune evasion - are common for both pathogens. It is also interesting that the strategy to achieve these common goals is quite different for each of the Candida species (Brunke \& Hube, 2013). A critical step for the development of fungal infection is adhesion to host cells and proteins through molecules exposed on the surface of Candida cells. It is well known that hyphal forms are mainly involved in this process in C. albicans. Since C. glabrata only exists in the yeast-like form, it had to develop a different strategy required for adhesion and invasion of host cells.

The genome of $C$. glabrata contains genes that encode 67 adhesin-like glycosylphosphatidylinositol(GPI)-anchored cell-wall proteins, which are classified into seven groups. The largest and best characterized is the Epa family, with Epa1, Epa6 and Epa7 being the most notable members. This group of proteins exhibiting diverse ligand-binding characteristics is involved in the interactions with epithelial and endothelial cells (de Groot et al., 2008; Diderrich et al., 2015). In terms of primary structures, Epas are similar to $S$. cerevisae Flo proteins and the members of the $C$. albicans Als family of typical adhesins that comprise three regions: a C-terminal domain with a GPI-anchor, a central domain with a heavily glycosylated Ser/Thr-rich region, and an N-terminal domain required for ligand recognition (Sheppard et al., 2004).

For all pathogens, the interplay between surfaceexposed proteins and human extracellular matrix proteins is an essential function that facilitates development of infection. $\mathrm{FN}$ has been proven to be important for tissue-attachment of many prokaryotic and eukaryotic pathogens such as Staphylococcus spp., Streptococcus spp. (Schwarz-Linek et al., 2004), Treponema pallidum (Dickerson et al., 2012), Trypanosoma cruzi (Pinho et al., 2002) and Candida spp. (Nett et al., 2006; Kozik et al., 2015). The knowledge on the interactions of $C$. glabrata adhesins with human $\mathrm{FN}$ is essentially limited to data on $\mathrm{FN}$ binding by an N-terminal fragment of Epa1, heterologously overproduced in E. coli. In the present study, we found a substantial body of evidence for the predominant role of Epa6 in the FN binding on the C. glabrata cell surface.

The proteins extracted from the cell wall of C. glabrata cultured in the RPMI 1640 medium were found to contain Epa6 and at the same time, to exhibit high FN binding activity, considerably higher than that of proteins isolated from the YPD-cultured yeast, among which no Epa6 could be detected. In contrast to $C$. albicans, C. glabrata does not produce hyphal or pseudophyphal forms in the RPMI 1640 medium (Hoyer et al., 1995). This implies that these two fungal species have independently evolved different strategies to detect the presence of host proteins. While the details differ, the basic principle is the same - upon detection of the host environment, adhesins are expressed to attach to the host cells (Brunke \& Hube, 2013).

In the fractions obtained from ion-exchange chromatography with the highest FN-binding activity, two members of the Epa family, i.e. Epa6 and Epa3, were identified by LC-MS/MS. Interestingly, in other studies, these particular adhesins were isolated from biofilm-forming cells, and a higher mRNA level for EPA6 was observed and correlated with increased virulence in hyper-adhesive clinical isolates (Gomez-Moler et al., 2015). The purification of Epa6 was completed using high performance gel filtration on the TSK G 3000 SW column, which yielded an acceptably pure protein preparation. It was subjected to direct FN-binding tests to confirm the actual formation of the complex of these two proteins and to determine the basic thermodynamic and kinetic parameters for this protein-protein interaction. The first method, i.e. the microplate ligand binding assay, is useful only for rough estimation of the dissociation constant; the second method, SPR measurements, facilitates precise determination of the kinetic constants for the complex formation and dissociation, as well as the thermodynamic dissociation constant. Only a few similar studies based on application of SPR measurements and performed for 
C. albicans have been reported so far and presented reports on binding of candidal cell wall proteins with proteinaceous components of the human extracellular matrix (Donohue et al., 2011; Jordan et al., 2014) and the plasma kinin-forming system (Seweryn et al., 2015). The interaction between the $\mathrm{N}$-terminal domain of Epa1 and $\mathrm{FN}$ was demonstrated in one report on $C$. glabrata, with an apparent $K_{\mathrm{D}}$ estimated at $9.11 \times 10^{-7} \mathrm{M}$ (Ielasi et al., 2014). In the present study, the dissociation constant for Epa6 binding to $\mathrm{FN}$ was determined to be lower by 1-2 orders of magnitude $\left(9.03 \times 10^{-9} \mathrm{M}\right.$ or $7.2 \times 10^{-8} \mathrm{M}$ by SPR or the microplate ligand-binding assay, respectively). These values should be classified as having moderate strength (Tudos \& Schasfoort, 2008). Comparable values of $K_{\mathrm{D}}$, in a range of $3-16 \times 10^{-9} \mathrm{M}$, were obtained using the SPR method for the interaction between $\mathrm{FN}$ and the recombinant domains of streptococcal and staphylococcal adhesins (Joh et al., 1999; Allignet et al., 2012).

Our findings suggest that Epa6 is an effective adhesin, capable of strong interaction with extracellular matrix. However, it is difficult to conclude about the relative FN-binding strength between different Epas, because the only reference SPR study (Ielasi et al., 2014) was performed on Epa1 N-terminal fragment heterologously expressed in bacteria and devoid of sugar elements which could be involved in FN binding. Our study aimed at purification of the natural, full length Epa6. During this purification procedure, Epa3 appeared in some fractions (Table 1) and, although not further purified, was determined by SPR to bind FN with the dissociation constant in micromolar range (results not presented). One should also bear in mind that the specificity of ligand binding demonstrated by these particular Epa proteins might be quite different. Previous studies showed that most Epas, including Epa1, Epa6 and Epa7 bind to galactose-containing oligosaccharides which occur, for instance, in mucin-type O-glycans (Zupancic et al., 2008; Maestre-Reyna et al., 2012; Diderrich et al., 2015).

The "cell surface shaving" approach has often been used for rapid analysis of changes occurring within the cell wall of live cells. The major advantage of this method is that, after a short incubation with trypsin, the cells remain viable and their membrane is not damaged (Olaya-Abril et al., 2014). This novel approach that allows identification of a number of surface-exposed proteins was successfully used for studying the cell surface of several bacterial species and, more recently, fungal opportunistic pathogens such as C. albicans (Hernáez et al., 2010; Vialás et al., 2012; Gil-Bona et al., 2015), C. parapsilosis and C. tropicalis (Karkowska-Kuleta et al., 2015). In the present study, the comparative analysis of the proteinaceous components of the $C$. glabrata cell wall demonstrated some changes on the fungal cell surface after 17 hours of growth in the presence of human FN. In these experiments, $\mathrm{FN}$ was used at a concentration of $200 \mu \mathrm{g} / \mathrm{ml}$, comparable to the physiological concentrations in human plasma (a range of $150-800 \mu \mathrm{g} / \mathrm{ml}$ ) (Garat et al., 1996).

Adhesive proteins exposed on the candidal cell surface might be classified into two groups. The first group contains classical adhesins equipped with a N-terminal signal peptide and exported outside the cell through the classical secretory pathway via the endoplasmic reticulum and Golgi apparatus (Pitarch et al., 2002; Klis et al., 2006). The second group of proteins often termed as 'atypical', consists of mainly cytoplasmic proteins with evolutionary conserved enzymatic functions whose exposition at the cell wall starts to be considered as a rule rather than an exception (Karkowska-Kuleta \& Kozik,
2014). In our work, besides the occurrence of several 'atypical' proteins, the presentation of a classical adhesin, Epa6, on the cell surface after addition of human FN to the culturing medium was the most important change observed in the cell wall proteome. Furthermore, while searching the data obtained against the SwissProt database with restriction to human proteins, we found FN to be adsorbed on the fungal cell surface. These findings support the hypothesis that FN binding to C. glabrata cell surfaces mainly depends on Epa6. On the other hand, several 'atypical' proteins that were identified could also play a role in this interaction, consistently with recent suggestions that $C$. parapsilosis elongation factor 2 , malate synthase, 6-phosphogluconate dehydrogenase and C. tropicalis enolase, fructose-bisphosphate aldolase, and transaldolase are involved in the interactions with human FN (Kozik et al., 2015).

Human FN is locally produced by fibroblasts, lymphocytes, macrophages, epithelial cells and vascular myocytes, and is present at a relatively high concentration in plasma (Alitalo et al., 1980; Magnuson et al., 1998; Lenselink, 2013). FN binding by C. glabrata may facilitate colonization of the host by preventing pathogen detachment, as reported for pathogenic bacteria, Streptococcus pyogenes or Staphylococcus aureus, which attached to epithelial cells throughout interactions with FN (Dziewanowska et al., 1999; Cue et al., 2000). In contrast to active, hypha-mediated penetration of epithelial and endothelial cells by $C$. albicans, $C$. glabrata is able to enter the bloodstream and spread relatively easily, even without damage to host cells, as shown in a chicken embryo model (Jacobsen et al., 2011) or a mouse model (Weastwatre et al., 2007) of candidal infection. Therefore, it was postulated that instead of active penetration, the mechanism of C. glabrata virulence and invasion may be based on endocytosis without damaging the host cell (Li et al., 2007). It is also well known that C. glabrata may exist for a long time within macrophages without inducing inflammation; therefore, the interactions with $\mathrm{FN}$ might facilitate phagocytosis of $C$. glabrata cells by macrophages in order to enter these host cells and survive within them, as reported for S. aureus (Shinji et al., 2003).

In conclusion, the present study clearly showed an interaction between Epa6 and FN that might be significant in the process of fungal adhesion to the proteins, cells, and tissues of the human host. As regards adhesins, which target host proteins as their binding ligands, the knowledge in this area is still insufficient, in contrast to the well-described lectin-type activity of Epa proteins. Investigations in this field would considerably improve our understanding of how this pathogenic yeast can cause a vast range of invasive as well as superficial infections in humans.

\section{Conflicts of interest}

The authors declare that there are no conflicts of interest.

\section{Acknowledgements}

This work was supported in part by the National Science Centre of Poland (grant no. 2012/07/B/ NZ1/02867 awarded to A.K.). Some equipment used in this study was purchased by the European Regional Development Fund as part of the Polish Innovation Economy Operational Program (contract no. POIG.02.01.0012-167/08, project Małopolska Center of Biotechnology). The Faculty of Biochemistry, Biophysics and Biotechnology of the Jagiellonian University in Krakow 
is a beneficiary of structural funds from the European Union (grant no. POIG.02.01.00-12-064/08, "Molecular biotechnology for health") and a partner of the Leading National Research Center (KNOW) supported by the Ministry of Science and Higher Education, Poland.

\section{REFERENCES}

Allignet J, England P, Old I, El Solh N (2002) Several regions of the repeat domain of the Staphylococcus caprae autolysin, AtlC, are involved in fibronectin binding. FEMS Microbiol Lett 213: 193-197. http://dx.doi.org/10.1111/j.1574-6968.2002.tb11305.x.

Bassetti M, Merelli M, Ansaldi F, de Florentiis D, Sartor A, Scarparo C, Callegari A, Righi E (2015) Clinical and therapeutic aspects of candidemia: a five year single centre study. PLoS One 10: e0127534. http://dx.doi.org/10.1371/journal.pone.0127534.

Brunke S, Hube B (2013) Two unlike cousins: Candida albicans and Candida glabrata infection strategies. Cell Microbiol 15: 701-708. http:// dx.doi.org/http://dx.doi.org/10.1111/cmi.12091.

Castano I, Pan SJ, Zupancic M, Hennequin C, Dujon B, Cormack BP (2005) Telomere length control and transcriptional regulation of subtelomeric adhesins in Candida glabrata. Mol Microbiol 55: 12461258. http://dx.doi.org/10.1111/j.1365-2958.2004.04465.x.

Chaffin WL (2008) Candida albicans cell wall proteins. Microbiol Mol Biol Rev 72: 495-544. http://dx.doi.org/10.1128/MMBR.00032-07.

Crowe JD, Sievwright IK, Auld GC, Moore NR, Gow NA, Booth NA (2003) Candida albicans binds human plasminogen: identification of eight plasminogen-binding proteins. Mol Microbiol 47: 1637-1651. http://dx.doi.org/10.1046/j.1365-2958.2003.03390.x.

Cue D, Southern SO, Southern PJ, Prabhakar J, Lorelli W, Smallheer JM, Mousa SM, Cleary PP (2000) A nonpeptide integrin antagonist can inhibit epithelial cell ingestion of Streptococcus pyogenes by blocking formation of integrin 51-fibronectin-M1 protein complexes. Proc Natl Acad Sci USA 97: 2858-2863. http://dx.doi.org/10.1073/ pnas.050587897.

de Groot PW, Kraneveld EA, Yin QY, Dekker HL, Gross U, Crielaard W, de Koster CG, Bader O, Klis FM, Weig M (2008) The cell wall of the human pathogen Candida glabrata: differential incorporation of novel adhesin-like wall proteins. Eukaryot Cell 7: 1951-1964. http://dx.doi.org/10.1128/EC.00284-08.

d'Enfert C, Janbon G (2016) Biofilm formation in Candida glabrata: What have we learnt from functional genomics approaches? FEMS Yeast Res 16: 1-13. http://dx.doi.org/10.1093/femsyr/fov111.

Dickerson MT, Abney MB, Cameron CE, Knecht M, Bachas LG, Anderson KW (2012) Fibronectin binding to the Treponema pallidum adhesin protein fragment rTp0483 on functionalized self-assembled monolayers. Bioconjug Chem 23: 184-195. http://dx.doi.org/10.1021/ bc200436x.

Diderrich R, Kock M, Maestre-Reyna M, Keller P, Steuber H, Rupp S, Essen LO, Mösch HU (2015) Structural hot spots determine functional diversity of the Candida glabrata epithelial adhesin family. J Biol Chem 32: 19597-19613. http://dx.doi.org/10.1074/jbc. M115.655654.

Donohue DS, Ielasi FS, Goossens KVY, Willaert RG (2011) The Nterminal part of Als1 protein from Candida albicans specifically binds fucose-containing glycans. Mol Microbiol 80: 1667-1679. http:// dx.doi.org/10.1111/j.1365-2958.2011.07676.x.

Dujon B, Sherman D, Fischer G, Durrens P, Casaregola S, Lafontaine I, et al. (2004) Genome evolution in yeasts. Nature 430: 35-44. http://dx.doi.org/10.1038/nature02579.

Dziewanowska K, Patti JM, Deobald CF, Bayles KW, Trumble WR, Bohach GA (1999) Fibronectin binding protein and host cell tyrosine kinase are required for internalization of Staphylococcus aureus by epithelial cells. Infect Immun 67: 4673-4678.

El-Kirat-Chatel S, Beaussart A, Derclaye S, Alsteens D, Kucharíková S, Van Dijck P, Dufrêne YF (2015) Force nanoscopy of hydrophobic interactions in the fungal pathogen Candida glabrata. ACS Nano 9: 1648-1655. http://dx.doi.org/10.1021/nn506370f.

Garat C, Kheradmand F, Albertine KH, Folkesson HG, Matthay MA (1996) Soluble and insoluble fibronectin increases alveolar epithelial wound healing in vitro. Am J Physiol 271: 844-853.

Ghosh K, Ren XD, Shu XZ, Prestwich GD, Clark R (2006) Fibronectin functional domains coupled to hyaluronan stimulate adult human dermal fibroblast responses critical for wound healing. Tissue Eng 12: 601-613. http://dx.doi.org/10.1089/ten.2006.12.601.

Gil-Bona A, Parra-Giraldo CM, Hernáez ML, Reales-Calderon JA, Solis NV, Filler SG, Monteoliva L, Gil C (2015) Candida albicans cell shaving uncovers new proteins involved in cell wall integrity, yeast to hypha transition, stress response and host-pathogen interaction. I Proteom 127: 340-351. http://dx.doi.org/10.1016/j.jprot.2015.06.006.

Gómez-Molero E, de Boer AD, Dekker HL, Moreno-Martínez A, Kraneveld EA, Ichsan, Chauhan N, Weig M, de Soet JJ, de Koster CG, Bader O, de Groot PW (2015) Proteomic analysis of hyperadhesive Candida glabrata clinical isolates reveals a core wall proteome and differential incorporation of adhesins. FEMS Yeast Res 8: 1-10. http://dx.doi.org/10.1093/femsyr/fov098.

Gupta A, Gupta A, Varma A (2015) Candida glabrata candidemia: An emerging threat in critically ill patients. Indian J Crit Care Med 19: 151-154. http://dx.doi.org/10.4103/0972-5229.152757.

Heilmann CJ, Sorgo AG, Klis FM (2012) News from the fungal front: wall proteome dynamics and host-pathogen interplay. PLoS Pathog $\mathbf{8}$ : e1003050. http://dx.doi.org/10.1371/journal.ppat.1003050.

Hernáez ML, Ximénez-Embún P, Martínez-Gomariz M, Gutiérrez-Blázquez MD, Nombela C, Gil C (2010) Identification of Candida albicans exposed surface proteins in vivo by a rapid proteomic approach. J Proteom 73: 1404-1409. http://dx.http://dx.doi.org/10.1016/j.jprot.2015.06.006.

Hoyer LL, Scherer S, Shatzman AR, Livi GP (1995) Candida albicans ALS1: domains related to a Saccharomyces cerevisiae sexual agglutinin separated by a repeating motif. Mol Microbiol 15: 39-54.

Ielasi FS, Verhaeghe T, Desmet T, Willaert RG (2014) Engineering the carbohydrate-binding site of Epalp from Candida glabrata: generation of adhesin mutants with different carbohydrate specificity. Glycobiol 24: 1312-1322. http://dx.doi.org/10.1093/glycob/cwu075.

Jacobsen ID, Grosse K, Berndt A, Hube B (2011) Pathogenesis of Candida albicans infections in the alternative chorio-allantoic membrane chicken embryo model resembles systemic murine infections. PLoS One 6: 19741-19754. http://dx.doi.org/10.1371/journal. pone.0019741.

Joh D, Wann ER, Kreikemeyer B, Speziale P, Hook M. (1999) Role of fibronectin-binding MSCRAMMs in bacterial adherence and entry into mammalian cells. Matrix Biol 18: 211-223.

Jordan RPC, Williams DW, Moran GP, Coleman DC, Sullivan DJ (2014) Comparative adherence of Candida albicans and Candida dubliniensis to human buccal epithelial cells and extracellular matrix proteins. Med Mycol 52: 254-263. http://dx.doi.org/10.1093/mmy/ myt032.

Karkowska-Kuleta J, Kozik A (2014) Moonlighting proteins as virulence factors of pathogenic fungi, parasitic protozoa and multicellular parasites. Mol Oral Microbiol 29: 270-283. http://dx.doi. org/10.1111/omi.12078.

Karkowska-Kuleta J, Zajac D, Bochenska O, Kozik A (2015) Surfaceome of pathogenic yeasts, Candida parapsilosis and Candida tropicalis, revealed with the use of cell surface shaving method and shotgun proteomic approach. Acta Biochim Pol 4: 807-819. http://dx.doi. org/10.18388/abp.2015_1140.

Kaur R, Domergue R, Zupancic ML, Cormack BP (2005) Expression of Candida glabrata adhesins following exposure to chemical preservatives. Curr Opin Microbiol 8: 378-384. http://dx.doi. org/10.1086/599120.

Klis FM, Boorsma A, De Groot PW (2006) Cell wall construction in Saccharomyces cerevisiae. Yeast 23: 185-202. http://dx.doi.org/10.1002/ yea.1349.

Kuhn DM, Vyas VK (2012) The Candida glabrata adhesin Epa1p causes adhesion, phagocytosis, and cytokine secretion by innate immune cells. FEMS Yeast Res 12: 398-414. http://dx.doi.org/10.1111/ j.1567-1364.2011.00785.x.

Laemmli UK (1970) Cleavage of structural proteins during the assembly of the head of bacteriophage T4. Nature 227: 680-685. http:// dx.doi.org/10.1038/227680a0.

Lenselink EA (2013) Role of fibronectin in normal wound healing. Int Wound J 12: 313-316. http://dx.doi.org/10.1111/iwj.12109.

Li L, Kashleva H, Dongari-Bagtzoglou A (2007) Cytotoxic and cytokine-inducing properties of Candida glabrata in single and mixed oral infection models. Microb Pathog 42: 138-147. http://dx.doi. org/10.1016/j.micpath.2006.12.003.

Maestre-Reyna M, Diderrich R, Veelders MS, Eulenburg G, Kalugin V, Brückner S, Keller P, Rupp S, Mösch HU, Essen LO (2012) Structural basis for promiscuity and specificity during Candida glabrata invasion of host epithelia. Proc Natl Acad Sci USA 109: 16864-16869. http://dx.doi.org/10.1073/pnas.1207653109.

Magnuson MK, Mosher DF (1998) Fibronectin: structure, assembly, and cardiovascular implications. Arterioscler Thromb Vasc Biol 18: 1363-1370.

Mikulska M, del Bono V, Ratto S, Viscoli C (2012) Occurrence, presentation and treatment of candidemia. Expert Rev Clin Immunol 8: 755-765. http://dx.doi.org/10.1586/eci.12.52.

Nett JE, Cabezas-Olcoz J, Marchillo K, Mosher DF, Andes DR (2016) Targeting fibronectin to disrupt in vivo Candida biofilms. Antimicrob Agents Chemother 60: 3152-3155. http://dx.doi.org/10.1128/ AAC.03094-15.

Olaya-Abril A, Jiménez-Munguía I, Gómez-Gascón L, Rodríguez-Ortega MJ (2014) Surfomics: shaving live organisms for a fast proteomic identification of surface proteins. J Proteom 97: 164-176. http:// dx.doi.org/10.1016/j.jprot.2013.03.035.

Perlroth J, Choi B, Spellberg B (2007) Nosocomial fungal infections: epidemiology, diagnosis, and treatment. Medic Mycol 4: 321-346. http://dx.doi.org/10.1080/13693780701218689.

Pfaller M, Neofytos D, Diekema D, Azie N, Meier-Kriesche HU, Quan SP, Horn D (2012) Epidemiology and outcomes of candi- 
demia in 3648 patients: data from the Prospective Antifungal Therapy (PATH Alliance $\left.{ }^{\circledR}\right)$ registry, 2004-2008. Diagn Microbiol Infect Dis 74: 323-331. http://dx.doi.org/10.1016/j.diagmicrobio.2012.10.003.

Pinho RT, Vannier-Santos MA, Alves CR, Marino AP, Castello Branco LR, Lannes-Vieira J (2002) Effect of Trypanosoma cruzi released antigens binding to non-infected cells on anti-parasite antibody recognition and expression of extracellular matrix components. Acta Trop 83: 103-15. http://dx.doi:10.1016/S0001-706X(02)00062-1.

Pitarch A, Sánchez M, Nombela C, Gil C (2002) Sequential fractionation and two dimensional gel analysis unravels the complexity of the dimorphic fungus Candida albicans cell wall proteome. Mol Cell Proteom 1: 967-982. http://dx.doi.org/10.1074/mcp.M200062-MCP200.

Polke M, Hube B, Jacobsen ID (2015) Candida survival strategies. Adv Appl Microbiol 91: 139-235. http://dx.doi.org/10.1016/ bs.aambs.2014.12.002.

Rapala-Kozik M, Karkowska J, Jacher A, Golda A, Barbasz A, Guevara-Lora I, Kozik A (2008) Kininogen adsorption to the cell surface of Candida spp. Int Immunopharmacol 8: 237-241. http:// dx.http://dx.doi.org/10.1016/j.intimp.2007.07.005.

Roetzer A, Klopf E, Gratz N, Marcet-Houben M, Hiller E, Rupp S, Gabaldón T, Kovarik P, Schüller C (2011) Regulation of Candida glabrata oxidative stress resistance is adapted to host environment. FEBS Lett 585: 319-27. http://dx.doi.org/10.1016/j.febslet.2010.12.006.

Schwarz-Linek U, Höök M, Potts JR (2004) The molecular basis of fibronectin-mediated bacterial adherence to host cells. Mol Microbiol 52: 631-641. http://dx.doi.org/10.1111/j.1365-2958.2004.04027.x.

Seweryn K, Karkowska-Kuleta J, Wolak N, Bochenska O, KedrackaKrok S, Kozik A, Rapala-Kozik M (2015) Kinetic and thermodynamic characterization of the interactions between the components of human plasma kinin-forming system and isolated and purified cell wall proteins of Candida albicans. Acta Biochim Polon 62: 825-835. http://dx.doi.org/10.18388/abp.2015_1142.
Sheppard DC, Yeaman MR, Welch WH, Phan QT, Fu Y, Ibrahim AS, Edwards JE (2004) Functional and structural diversity in the Als protein family of Candida albicans. J Biol Chem 279: 30480-30489. http://dx.doi.org/10.1074/jbc.M401929200.

Shinji H, Seki K, Tajima A, Uchida A, Masuda S (2003) Fibronectin bound to the surface of Staphylococcus aureus induces association of very late antigen 5 and intracellular signaling factors with macrophage cytoskeleton. Infect Immun 71: 140-146. http://dx.doi. org/10.1128/IAI.71.1.140-146.2003.

Sturtevant J. Calderone R (1997) Candida albicans adhesins: Biochemical aspects and virulence. Rev Iberoam Micol 14: 90-97.

Tadec L, Talarmin JP, Gastinne T, Bretonniere C, Miegeville M, La Pape P, Morio F (2016) Epidemiology, risk factor, species distribution, antifungal resistance and outcome of Candidemia at a single French hospital: a 7-year study. Mycoses 25: 1-8. http://dx.doi. org/10.1111/myc. 12470 .

Tate MC, Shear DA, Hoffman SW, Stein DG, Archer DR, LaPlaca MC (2002) Fibronectin promotes survival and migration of primary neural stem cells transplanted into the traumatically injured mouse brain. Cell Transplant 3: 283-295. http://dx.doi. org/10.0000/096020198389933.

Vialás V, Perumal P, Gutierrez D, Ximénez-Embún P, Nombela C, Gil C, Chaffin WL (2012) Cell surface shaving of Candida albicans biofilms, hyphae, and yeast form cells. Proteomics 12: 2331-2339. http:// dx.doi.org/10.1002/pmic.201100588.

Westwater C, Schofield DA, Nicholas PJ, Paulling EE, Balish E (2007) Candida glabrata and Candida albicans; dissimilar tissue tropism and infectivity in a gnotobiotic model of mucosal candidiasis. FEMS Immunol Med Microbiol 51: 134-139. http://dx.doi.org/10.1111/j.1574695X.2007.00287.x.

Zupancic ML, Frieman M, Smith D, et al. (2008) Glycan microarray analysis of Candida glabrata adhesin ligand specificity. Mol Microbiol 68: 547-59. http://dx.doi.org/10.1111/j.1365-2958.2008.06184.x 